AT-TAJDID: Jurnal Pendidikan Dan Pemikiran Islam

(p-ISSN: 2548-5784 |e-ISSN: 2549-2101)

Vol. (5) (01), (Januari-Juni) (2021), (50-61)

Doi: http://dx.doi.org/10.24127/att.v5i01.1523

\title{
RELIGIUSITAS UNIVERSITY: \\ STRATEGI INTERNALISASI NILAI-NILAI AIK DALAM MEMBANGUN KULTUR RELIGIUS UNIVERSITAS MUHAMMADIYAH METRO
}

\author{
Junaidi Songidan ${ }^{1}$ \\ junaidisongidan@gmail.com ${ }^{1}$ \\ Universitas Muhammdiyah Metro ${ }^{1}$ \\ Heri Cahyono ${ }^{2}$ \\ hericahyono808@gmail.com² \\ Universitas Muhammdiyah Metro $^{2}$ \\ Liana Fadhilah ${ }^{3}$ \\ lianafadhila@gmail.com ${ }^{3}$ \\ Universitas Muhammdiyah Metro ${ }^{3}$
}

\begin{abstract}
ABSTRAK
Tingginya jumlah amal usaha pendidikan Muhammadiyah memberikan kesempatan dalam mendaakwahkan nilai-nilai Al-Islam dan Kemuhammadiyahan secara lebih luas. Sudah sepatutnya Lembaga Pendidikan Muhammadiyah Memiliki strategi dalam menginternalisasikan nilai-nilai AIK kedalam keperibadian maupun lembaga sebagai keberlangsungan Muhammadiyah sebagai gerakan Islam. Tujuan penelitian ini Mengungkap strategi internalisasi nilai-nilai AIK di Universitas Muhammadiyah Metro, fenomena kultur religius di Universitas Muhammadiyah Metro. Jenis penelitian ini adalah penelitian lapangan, yaitu penelitian yang dilakukan dalam kehidupan yang sebenarnya. Penelitian ini menggunakan pendekatan deskriptif eksplanatori. Dalam internalisasi nilainilai religius di lembaga pendidikan tidak instan sehingga perlu dilakukan secara kontinue. Sehingga dalam menginternalisasikan nilai-nilia tersebut membutuhkan berbagai macam cara sebagaimana yang dikemukakan oleh agus wibowo yakni dengan keteladanan, latihan dan pembiasaan dan pemberian nasihat. Internalisasi nilai-nilai Islam (AIK) kedalam kompetensi pribadi dosen, karyawan dan mahasiswa UM Metro menjadi ciri khas pada penyelenggaraan pendidikan Muhammadiyah untuk membentuk manusia pembelajar yang bertaqwa, berakhlakul karimah, berkemajuan dan unggul dalam IPTEKS sebagai perwujudan tajdid dakwah amar ma'ruf nahi munkar.
\end{abstract}

Kata Kunci: Strategi, Nilai, Kultur Religius

\begin{abstract}
The high number of Muhammadiyah educational charities provides an opportunity to preach the values of Al-Islam and Muhammadiyah to a wider extent. It is fitting for Muhammadiyah Educational Institutions to have a strategy in internalizing the values of AIK into personality and institutions as a continuation of Muhammadiyah as an Islamic movement. The purpose of this research is to reveal the strategy of internalizing the values of AIK at Muhammadiyah
\end{abstract}


Metro University, the phenomenon of religious culture at Muhammadiyah Metro University. This type of research is field research, namely research conducted in real life. This research uses an explanatory descriptive approach. The internalization of religious values in educational institutions is not instant, so it needs to be done continuously. So that in internalizing these values requires a variety of ways as suggested by Agus Wibowo, namely by modeling, training and habituation and giving advice. Internalization of Islamic values (AIK) into the personal competences of UM Metro lecturers, employees and students is a hallmark of the implementation of Muhammadiyah education to form human learners who are devout, have good character, progress and excel in science and technology as a manifestation of tajdid da'wah amar ma'ruf nahi munkar .

Keywords: Strategy, Value, Religious Culture

\section{A. PENDAHULUAN}

Sejak tahun 1912 Muhammadiyah lahir membwa gerakan pada bidang keagamaan, pendidikan dan kemasyarakatan. Khusunya dalam bidang pendidikan Muhammadiyah mengalami perkembangan yang sangat pesat hingga pada tahun 2019 terdapat $6.623 \mathrm{TK} / \mathrm{TPQ}$, 2.604 SD/MI, 1.772 SMP/MTs, 1.143 SMA/MA/SMK, 172 Perguruan Tinggi (http://www.muhammadiyah.or.id).

Tinginya jumlah amal usaha pendidikan Muhammadiyah memberikan kesempatan dalam mendaakwahkan nilai-nilai Al-Islam dan Kemuhammadiyahan secara lebih luas. Sudah sepatutnya Lembaga Pendidikan Muhammadiyah Memiliki strategi dalam menginternalisasikan nilai-nilai AIK kedalam keperibadian maupun lembaga sebagai keberlangsungan Muhammadiyah sebagai gerakan Islam.

Banyaknya pernyataan bahwa pendidikan nilai dibangun pada saat anakanak sehingga membutuhkan orang dewasa sebagai fasilitatornya. disadari atau tidak pernyataan tersebut mengisyaratkan bahwa jenjang pendidikan tinggi tidak lagi memberi formasi pendidikan nilai sebagai pendukung dalam membangun kultur yang religious. Pendidikan nilai yang terkristal dalam Akhlakul karimah perlu dibangun sejak anak anak berusia 12 sampai dengan 20 tahun, pada fase ini sebagai fasi dimana seseorang menentukan arah pengembangan keperibadianya (Sunaryo, 2004). Namun pendidikan tinggi sebagai pendidikan yang sama memiliki kewajiban dalam andil melaksanakan pendidikan nilai sebagai pembentukan karakter bangsa maka hal tersebut selaras dengan kondisi tenaga pendidikan di perguruan tinggi yang memiliki tugas utama dalam mengtransformasikan, mengembangkan serta menyebarluaskan ilmu pengetahuan melalui tri dharma perguruan tinggi. Selai itu tenaga pendidik di perguruan tinggi juga sebagai pengajar, pendidik, pelatih sehingga dapat mengembangakan aspek kognitif, afektif dan psikomotorik mahasiswa.

Kebijakan pendidikan nilai melalui Al-Islam dan Kemuhammadiyahan tidak lepas dari Keputusan Majlis Pendidikan Tinggi Pimpinan Pusat Muhammadiyah yang tertuang dalam buku pedoman pendidikan AIK (Al-Islam dan Kemuhammadiyahan di Perguruan Tinggi Muhammadiyah), Al-Islam dan Kemuhammadiyahan memiliki tujuan 
sebagai Being religious and humane Muslim berkemajuan (Pedoman AIK). Artinya dari secara implementatif internalisasi nilai perlu dilakukan sejak pendidikan dasar hingga pendididikan tinggi.

Secara filosofis kehadiran Muhammadiyah tidak lepas dari berbagai macam kegelisahan dan keperihatinan masalah social, religious dan moral. Kegelisahan moral disebabkan oleh kaburnya batas antara baik dan buruk pantas dan tidak pantas (Ensiklopedi Muhammadiyah).

Universitas

Muhammadiyah Metro meletakan Agama sebagai pondasi dalam pelaksanaan akademik. Budaya akademik yang dibangun berlandaskan Al-Quran dan Hadist. Nilai nilai yang terkandung di dalam Al Quran dan Hadist ini kemudian di perkuat dengan petunjuk teknis dari gerakan Muhammadiyah sebagai organisasi kemasyarakatan sebagai bentuk tanggung jawab dalam amal makruf nahi munkar.

Universitas muhammadiyah metro melalui visinya Terintegrasinya Nilai-nilai Islam dalam Kompetensi Individu dan Lembaga (https://ummetro.ac.id) menunjukan bahwa terdapat usaha serius dalam menciptakan kampus yang religious, banyak hal yang Nampak dilakukan sebagai upaya internalisasi nilai-nilai Al-Islam terhadap warga kampus. Selain itu juga Universitas Muhammadiyah Metro masuk kedalam peringkat 96 besar terbaik di Top Islamic Universities in the World tahun 2019 dari 13.000 Universitas di 200 Negara (https://www.ngopibareng.id). Hal ini menjadi alasan penting bagi peneliti untuk mengeksplor secara mendalam terhadap strategi internalisasi nilai-nilai AIK dalam membangun budaya hidup Islami.

Dari fenomena komitmen Universitas Muhammadiyah Metro dalam melaksanakan pendidikan nilai Al-Islam yang telah terbukti memberikan dampat sehingga tercatat sebagai Top Islamic Universities in the World membuktikan bahwa ada strategi yang dilakukan kampus dalam menginternalisasikan nilai-nilai AIK tersebut kedalam keperibadian pegawai mapun lembaga sehingga penulis tertarik untuk mengeksplorasi secara mendalam terkait dengan Strategi Internalisasi NilaiNilai Aik Dalam Membangun Kultur Religius Pegawai Universitas Muhammadiyah Metro.

\section{B. METODE PENELITIAN}

Jenis penelitian ini adalah penelitian lapangan, yaitu penelitian yang dilakukan dalam kehidupan yang sebenarnya (Mardalis, 2009). Penelitian ini menggunakan pendekatan deskriptif eksplanatori. Pendekatan ini dipilih karena dalam studi penelitian ini diharapkan akan dapat melibatkan peneliti kedalam penyelidikan yang lebih mendalam dan pemeriksaan menyeluruh terhadap strategi internalisasi nilai-nilai AIK terhadap masyarakat kampus.

Data penelitian ini adalah kualitatif lapangan (field research) maka pengumpulan data dalam penelitian ini. Sumber data dalam penelitian ini dikategorikan dalam dua kelompok besar: Pertama, sumber data primer, yaitu data yang diperoleh secara langsung dari subyek. Untuk memperoleh data ini, peneliti akan melakukan wawancara (interview) dengan beberapa informan. Kedua, sumber data sekunder, yaitu diperoleh dengan melakukan studi literatur dan studi dokumen seperti buku, jurnal, artikel dan 
majalah baik cetak maupun elektronik yang terkait dengan penelitian ini. Adapun pengumpulan data dalam penelitian ini menggunakan metode wawancara, dokumentasi dan observasi.

Sementara terkait dengan analisis data, dalam penelitian ini data yang bersifat kualitatif, setelah dikumpulkan kemudian dianalisis dengan metode deskriptis-analitis, yaitu suatu metode dalam meneliti status kelompok manusia, suatu obyek, situasi serta kondisi, dan sistem pemikiran. Tujuan dari penelitian deskriptif ini adalah untuk mendeskripsikan, menggambarkan atau melukiskan secara sistematis, fenoemna faktual dan akurat mengenai fakta-fakta serta hubungan antar fenomena yang diselidiki (Muhammad Nazir, 1988).

Analisis data dilakukan dengan menggunakan langkah-langkah sebagai berikut: Pertama, pengumpulan data, yaitu kegiatan uantuk menemukan dan menghimpun sumber-sumber informasi yang relevan dengan penelitian. Kedua, interprestasi data, yaitu tahap penyusunan fakta dalam kerangka logis dan harmonis, sehingga menjadi kesatuan yang utuh. Kegiatan penyusunan ini disebut juga dengan proses sintesis atau interprestasi. Ketiga, penulisan, yaitu tahap ketika hasil interprestasi ditulis secara sistematis, logis, harmonis, dan konsisten, baik dari segi kata maupun alur pembahasan. Secara teoritik, analisis data adalah proses menyusun, mengkategori, mencari pola atau tema dari data yang ada dengan maksud untuk memahami maknanya (Lexy J. Moleong, 1989).

Dalam penelitian kualitatif ini, terdapat tiga komponen pokok yang akan dilalui peneliti, yaitu data reduction, data display, dan conclusion drawing (Heribertus Sutopo, 1988). Tiga komponen analisis ini berlaku saling menjamin, baik sebelum, pada waktu, dan sesudah pelaksanaan pengumpulan data secara paralel yang disebut dengan model analisis mengalir (flow model of analysis).

\section{HASIL DAN PEMBAHASAN}

1. Pentingnya internalisasi nilai-nilai AIK di Perguruan Tinggi

Nilai-nilai

Al-Islam dan

Kemuhammadiyahan merupakan sebagai cikal akal adanya perguruan tinggi Muhammadiyah, jika dilihat dari struktur alur adanya perguruan tinggi Muhammadyah ada karena adanya Al-Islam dan Kemuhammadiyahan, begitu juga dengan adanya AIK karena adanya Perserikatan Muhammadiyah dan adanya perserikatan Muhammadiyah karena adanya jasa sang kiyai Ahmah Dahlan sebagai pendiri. Menggunakan Bahasa yang dikemukakan Tabroni (Majlis Dikti PPM: 2016) bahwa pembelajaran Al-Islam dan Kemuhammadiyahan ibarat sebuah pelatuk, dengan majunya Al-Islam dan Kemuhammadiyahan maka akan maju pula Perguruan Tinggi Muhammadiyah dimanapaun berada. Sehingga dilihat dari hakikat keberadaannya maka tujuan dari hadirnya AIK tidak lain adalah sebagai state of mind menjadi Islam yang benar, menjadi muslim yang baik (berkemajuan dan philantropis), penggerak agama dalam masyarakat, dan menjadi pemimpin (Tabroni: 2016).

Dilihat secara umum bahwa nilai-nilai Al-Islam dan Kemuhammadiyahan setidaknya terdapat lima nilai yang menjadi kunci kemajuan suatu individu maupun sebuah lembaga Instansi diantaranya adalah Nilai Islam, Nilai Ilmu, Nilai Iman, Nilai Ihsan dan Nilai Islah. Dengan nilai-nilai tersebut akan dapat terciptanya kecerdasan personal sehingga terwujudlah inovasiinovasi terbaru yang mampu menjawab setiap tantangan masa depan. Dalam amal usaha pendidikan Muhammadiyah tidak lepas sebagai langkah dan strategi dalam membumikan nilai-nilai Islam yang sebenar-benarnya sehingga nilai-nilai 
religious menjadi bahan yang ditransfer kepada seluruh warga lembaga pendidikan tersebut sebagaimana halnya makna pendidikan yang dikemukakan oleh Syaiful bahwa pendidikan merupakan usaha keseluruhan dalam melakukan transformasi ilmu pengetahuan, ide gagasan, hukum, norma dan nilai-nilai kepada orang lain dengan cara-cara tertentu baik secara formal maupun non formal dalam sebuah pendidikan. (syaiful Sagala: 2000)

Secara sederhana dilihat dari tujuanya bahwa tujuan pendidikan nilai bertujuan untuk mejadikan manusia berbudi pekerti luhur sebagai pondasi dalam menjalani kehidupan yang lebih bermartabat sebagaimana Rosulullah diutus oleh Allah di muka bumi ini untuk menyempurnakan akhlak. Hal ini diriwayatkan dalam sabda Nabi Muhammad SAW:

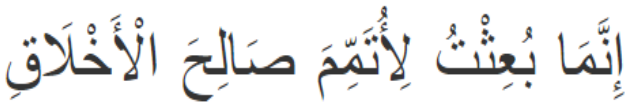

INNAMAA BU'ITS-TU LI-UTAMMIMA SHOOLIHAL AKHLAAQI

Artinya: Sesungguhnya aku (Rosulullah SAW) diutus untuk menyempurnakan akhlak yang baik (HR. Ahmad 2/381)

Dari sabda Nabi Muhammad SAW diatas menunjukan bahwa betapa pentingnya Internalisasi nilai-nilai Islam kedalam individu manusia agar memiliki akhlak yang mulia yang dapat mewarnai kehidupan di lingkunganya sehingga mampu tercipta lingkungan yang bernuansa religious.

Internalisasi nilai-nilai AIK kedalam kompetensi pribadi dosen dan karyawan UM Metro menjadi ciri khas pada penyelenggaraan pendidikan Muhammadiyah untuk membentuk manusia pembelajar yang bertaqwa, berakhlakul karimah, berkemajuan dan unggul dalam IPTEKS sebagai perwujudan tajdid dakwah amar ma'ruf nahi munkar sesuai dengan amanah yang tertuang dalam Putusan Muktamar Muhammadiyah ke-46 tentang Revitalisasi Pendidikan Muhammadiyah.
Visi tersebut secara tidak langsung mewajibkan seluruh PTM termasuklah Universitas Muhammadiyah Metro untuk melakukan internalisasi nilai-nilai AIK kedalam kompetensi pribadi dosen dan karyawan UM Metro dengan cara meningkatkan mutu dalam berbagai aspek termasuk Pendidikan Al-Islam dan Kemuhammadiyahan sebagai salah satu misi Muhammadiyah dalam dakwah.

Untuk mendukung visi yang termaktub dalam putusan tersebut dan merujuk pada Pedoman Pendidikan AIK Majelis Dikti PP Muhammadiyah dan Kemuhammadiyahan (2013) menyatakan bahwa Al-Islam dan Kemuhammadiyahan idealnya menjadi ruh/spirit dan visi bagi mata kuliah lain, bukan semata-mata beridiri sendiri secara terpisah sebagai salah satu mata kuliah. Bagi PTMA, sifat kurikulum AIK yang saat ini masih terpisah (separated) perlu diubah menjadi suatu kurikulum yang bersifat integratif (integrated) dan interkonektif dengan mata kuliah lain. Internaslisasi Nilai AIK tersebut selanjutnya diinternalisasikan sebagai value yang menjiwai seluruh seluruh dosen karyawan bahkan mahasiswa serta dalam kehidupan. Hal tersebut sejalan dengan tujuan pendidikan dalam pandangan pendiri Muhammadiyah KH. Ahmad Dahlan dengan rumusan formal tujuan pendidikan Muhammadiyah. Sedikitnya ada tiga tali yang menghubungkan keduanya, yaitu religiusitas (kyai, manusia, muslim), pertumbuhan pribadi secara optimal (kemajuan, berakhlak, cakap, percaya diri) dan berguna (bermanfaat, berfungsi, pragmatis) atau mengamalkan agama dan ilmu pengetahuan untuk memahami dan memecahkan kehidupan sosial sehingga ada kemajuan masyarakat sehingga dapat tercapai internalisasi nilainilai AIK kedalam kompetensi pribadi dosen dan karyawan dan mahasiswa UM Metro maka dilakukan proses internalisasi (pemahaman dan pembelajaran AIK, 
implementasi, pelatihan dan pendampingan pengamalan AIK), serta integrasi (penelitian dan pengembangan AIK).

Universitas muhammadiyah Metro diharapkan mampu mencetak figurfigur ulamayang intelek profesional atau profesional yang ulama. Oleh karena itu, Perguruan Tinggi Islam perlu untuk mengadakan perekonfigurasian tujuan institusionalnya dengan memperhatikan berbagai tuntutan masyarakat dan zaman yang terus berubah. Jika tidak, maka Universitas muhammadiyah Metro tidak pernah bartahan hidup dalam budaya dan umatnya sendiri seiring dengan pergeseran nilai yang semakin deras. (Maka internalisasi nilai-nilai Islam di Universitas muhammadiyah Metro sangat penting untuk dilakukan, agar terdapat keseimbangan antara penguasaan ilmu pengetahuan dan teknologi (Iptek) dengan penanaman keimanan dan ketakwaan (Imtaq). Dengan demikian Perguruan Tinggi Islam akan dapat menghasilkan lulusan yang berkualitas tinggi, yakni selain memiliki pengetahuan dan keahlian juga memiliki bekal ilmu pengetahuan agama, moral, akhlak yang mulia, serta amal shalih.

Dari pemaparan diatas maka dapat ditarik garis besarnya bahwa Pendidikan AIK di Universitas Muhammadiyah Metro menempati posisi strategis, bahkan menjadi ruh penggerak dan misi utama penyelenggaraan Universitas Muhammadiyah Metro. Pendidikan AlIslam dan Kemuhammadiyahan juga menjadi kekuatan Universitas Muhammadiyah Metro, karena bisa menjadi basis kekuatan spiritual, moral, dan intelektual serta daya gerak bagi seluruh civitas akademik. Pendidikan AIK juga sebagai identitas karakter civitas akademik Universitas Muhammadiyah Metro, yaitu sebagai muslim yang berkemajuan, berakhlak mulia, berjiiwa kesatria, memiliki karisma kepemimpinan, dan peduli terhadap persoalan umat dan bangsa. Peningkatan mutu proses dan hasil (outcome) pendidikan AIK harus dilaksanakan terus-menerus dan tersistem.

2. Strategi Internalisasi nilai-nilai AIK di Universitas Muhammadiyah Metro

Nilai merupakan harga atau kualitas yang diberikan oleh seseorang atau kelompok terhadap sesuatu, sehingga sesuatu itu menjadi perkara yang diperlukan, diusahakan dan dicari untuk dimiliki atau dimanfaatkan (Syihabuddin, 2019). Sehingga dalam mengimplementasikan dan menginternalisasikan nilai-nilai AIK di Universitas Muhammadiyah Metro maka setiap penyelenggara pendidikan dalam hal ini adalah pimpinan tertinggi perlu menerapkan berbagai macam strategi yang tepat. Karena setiap kebijakan yang dituangkan akan memiliki dampak pengaruh terhadap iklim di lembaga yang dipimpinnya. Penggunaan strategi yang tepat akan sangat memiliki pengaruh terhadap pemahaman-pemahaman individu dan pengamalan terhadap pemahaman yang disampaikan dalam diri sendiri maupun secara kelembagaan (Kristiawan et al., 2021). Sehingga penggunaan strategi internalisasi nilai yang tepat akan memiliki dapat yang baik terhadap tujuan yang diharapkan. Sebagaimana hasil pengamatan penulis terhadap kebijkan dan strategistrategi yang dibangun lembaga dalam menginternalisasikan nilai-nilai AIK setidaknya terdapat beberapa strategi sebagaimana penulis kemukakan dibawah ini:

\section{a. Power strategi}

Power strategi merupakan salah satu dari beberapa strategi dalam melakukan Internalisasi nilai-nilai AIK yang dibangun di lingkungan Universitas Muhammadiyah Metro. Pada strategi ini pimpinan memiliki peran yang sangat strategis melakukan pengembangan dan perintah terhadap inidividu lainya seperti halnya dosen, 
karyawan dan mahasiswa melalui berbagai macam kebijakan-kebijakan yang mengarah terhadap arah strategis internalisasi nilai. Seperti halnya yang dikemukakan oleh Ihsan bahwa pimpinan memiliki peran yang bersifat strategis dalam pembangunan kampus religius. Oleh karena itu terutama Wakil rektor bidang AIK harus berkoordinasi, berkonsultasi, berkomunikasi (3K) dengan Rektor dan wakil Rektor lainnya serta Unit AIK dan Rekan - rekan Fakultas Agama Islam agar dapat melakukan kebijakan perlu dikelola dengan baik sehingga dapat mencapai visi dan misi yang telah diharapkan. Sehingga peran wakil rektor 4 rektor di UM Metro sebagai bagian dari pimpinan perguruan tinggi menjadi sangat penting dan menentukan dalam keberhasilan Universitas Muhammadiyah Metro sesuai dengan pedoman sistem penjaminan mutu internasl perguruan tinggi Muhammadiyah Aisyiyah (SPMI PTMA) yang telah dibuat bukunya oleh Majelis Dikti PP Muhamadiyah yang berisi tetnttang visi, misi, tujuan dan segala kebijakan yang telah ditetapkan.

b. Keteladanan

Didalam sebuah lembaga pendidikan agar terbentuknya sebuah lembaga yang memiliki nuansa religious maka dibutuhkan contoh teladan dari individu yang lebih dewasa dan para pimpinan diatasnya yang memiliki wewenang terhadap lembaga yang dipimpinnya. Karena pada dasarnya naluri manusia adalah taqlid atau meniru setiap yang hadir di lingkunganya baik dalam ucapan, perbuatan maupun sikap, baik sikap kepada sesama mapun sikap terhadap sang Khaliknya. Oleh sebab itu dalam hal ini Rektor, Dosen, Karyawan adalah sebagai teladan terhadap satu sama lain terlebih bagi para mahasiwa di dalam lingkunga kampus karena strategi ini merupakan sebagai strategi yang cukup efektif dilakukan didalam dunia pendidikan. Hal inilah yang dikembangkan oleh Universitas
Muhammadyah Metro dalam menciptakan nuansa religious sebagaimana yang dikemukakan oleh wakil rector IV bidang AIK bahwa:

Kepemimpinan adalah sebuah proses dimana pemimpin yang menjadi contoh terhadap bawahannya dalam segala hal untuk mencapai tujuan bersama. Kepemimpinan merupakan faktor penting dalam keberhasilan suatu organisasi, khususnya di kampus UM Metro. Maka dari itu ada beberapa sikap kepemimpinan di kampus UM Metro yaitu:

1. Menjalin hubungan yang baik dengan bawahan

2. Memberi kepercayaan dan tanggung jawab

3. Memberi motivasi dan semangat kerja Banyak orang mengira pemimpin mendominasi suatu organisasi, misalnya dikampus Muhammadiyah karena merasa menguasai dan memiliki hak untuk mengatur segalanya. Tipe pemimpin yang seperti ini selalu mementingkan diri sendiri daripada kinerja perusahaan. Hal ini membentuk seorang pemimpin gagal dalam mempengaruhi bawahannya tetapi malah memerintah. Pemimpin yang baik adalah yang bisa mengayomi bawahannya untuk mencapai tujuan, sehingga bawahan tidak merasa ditindas. Agar seseorang dapat menjalankan organisasi dengan baik,maka seorang pemimpin butuh pelatihan dan pengalaman yang matang dalam bidangnya, Alhamdulillah di kampus Universitas Muhammadiyah metro tidak terjadi dalam hal itersebut, bahkan kami bagian dari Pimpinan khususnya di Universitas Muhammadiyah Metro sudah menjadi kewajiban menjadi contoh dalam bersikap, bicara dan bertindak, karena setiap rapat pimpinan kami selalu dievaluasi oleh Rektor Universitas Muhammadiyah Metro agar menjadi suri tauladan dalam segala hal. 
c. Latihan pembiasaan

Kegiatan internalisasi nilai di lingkungan pendidikan membutuhkan proses yang cukup lama secara kontinu sebagai langkah dalam membentuk kebiasaan-kebiasaan positif sehingga dalam strategi pembiasaan ini menjadi sebuah metode yang efektif dilakukan dalam kehidupan sehari-hari sebagai rutinitas yang baik hingga munculah kesadaran dalam diri secara mendalam betapa pentingnya menjalankan nilai-nilai Islami.

Pimpinan di Universitas Muhammadiyah Metro telah membuat kebijakan-kebijakan dalam pelaksanaan pendidikan nilai di kampus baik secara tertulis mapun secara lisan, baik yang tertuang didalam kurikulum maupun secara hiden kurikulum. Terdapat beberapa kegiatan rutinitas yang dilakukan Kampus dalam menginternalisasikan nilai-nilai AIK kedalam individu warga kampus diantaranya adalah:

Pertama Ngaji pagi. Dalam berbagai pertemuan internal dosen mapun karyawan Universitas Muhammadiyah Metro, Rektor selalu menyampaikan dan mengajak dosen dan karyawan untuk membiasakan kegitankegiatan rohani dengan membaca al-Qur'an setiap pagi menjelang bekerja sebagai awal kegiatan yang baik di ruangan kerja masing-masing.

Kedua Shalat dhuha. Shalat dhuha sebagai shalat yang memiliki banyak keuatamaan didalamnya dan yang menjadi salahsatu keutamaanya adalah sebagai pengganti sedekah terhadap anggota badan, manusia memiliki 360 sendi yang setiap sendinya memiliki hak sedekah disetiap harinya sehingga Rosulullah memberikan solusi praktis untuk mengatasi semua itu yakni dengan melaksanakan shalat dhuha setiap harinya. Hal itulah yang kemudian menjadi salah satu daya tarik warga kampus untuk istiqomah dalam melaksanakan shalat dhuha setiap pagi dan juga menyadari banyak keutamaan lainya didalamnya. Kebiasaan tersebut dapat dilihat dari banyaknya warga kampus yang melaksanakan shalat dhuha di Masjid Ulul Albab dan mushalla di kampus II dan kampus III.

Ketiga Shalat berjamaah. Shalat berjamaah khusunya shalat dzuhur di lingkungan kampus Universitas Muhammadiyah Metro menjadi sebuah kewajiban bagi seluruh dosen, karyawan dan mahasiswa. Terdapat beberapa pendukung structural dan kultural yang dilakukan oleh Universitas Muhammadiyah Metro dalam meramaikan shalat berjamaah di Masjid Ulul Albab seperti halnya disetiap waktu menunjukan pukul 11.45 seluruh gerbang dilingkungan kampus mulai ditutup dan tidak diperkenankan keluar masuk kampus. Selain itu juga disetiap berlangsungnya kegiatan pembelajaran yang berbenturan dengan jadwal pelaksanaan shalat maka seluruh kegiatan pembelajaran ditunda sementara dan seluruh mahasiswa diarahkan untuk melaksanakan shalat berjamaah.

Keempat Senyum, salam, sapa. Pembiasaan melakukan 3S (senyum, salam, sapa) dilakukan pada kegiatan sehari-hari, kegiatan ini dimaksud untuk memberikan pengajaran terhadap seluruh warga kampus tentang pentingnya dan manfaatnya menjadi hubungan silaturahmi dan kekeluargaan satu sama lain. Hingga saat ini warga kampus Universitas Muhammadiyah Metro tidak terlepas dosen, karyawan dan mahasiswa selu melaksanakan sikap $3 \mathrm{~S}$ tersebut baik didalam mapun dilur kelas disetiap satu sama lain berjumpa.

d. Nasihat

Nasihat (Mau'izhah al-Hasanah) menjadi salah satu strategi yang mampu membukakan mata hati manusia agar mampu menuju derajat yang lebih mulia bersama prinsip-prinsip Islam. Dengan adanya strategi nasihat dalam menginternalisasikan nilai-nilai AIK akan 
sangat berpengaruh terhadati hati yang bersih, jiwa yang tenang, sikap yang bijak. Bahkan al-Qur'an sudah mengisyaratkan betapa pentingnya nasihat atau peringatan bagi manusia seperti halnya didalam QS. Qaaf $50: 37$.

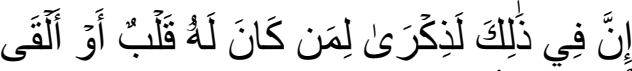

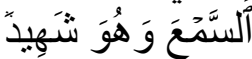

Artinya: sesungguhnya pada yang demikian itu benar-benar terdapat peringatan bagi orang-orang yang mempunya akal atau yang menggunakan pendengaranya, sedangkan dia menyaksikanya.

Universitas Muhammadiyah Metro sudah sejak lama melaksanakan strategi nasihat sebagai salah satu strategi dalam menginternalisasikan nilai-nilai AIK kedalam kopetensi pribagi warga kampus. Ada beberapa kegiatan dalam penyampaian nasihat yang dilakukan pimpinan atau satu sama lain warga kampus Universitas Muhammadiyah Metro, yakni dengan adanya kajian dhuha yang dimotori oleh Badan Pembina Harian (BPH) kampus yang dilaksanakan setiap hari jum'at pagi. Selain itu juga ada kegiatan kultum dzhur yang dimotori oleh seluruh dosen sebagaimana jadwal yang disusun oleh takmir masjid Ulul Albab.

\section{Kultur religious di Universitas}

Muhammadiyah Metro

Setiap lembaga pendidikan selain memiliki budaya akademik sebagai identitas lembaga pendidikan, namun dengan semakin pesatnya persaingan dunia pendidikan dalam hal ini adalah perguruan tinggi untuk menjadi perguruan tinggi terbaik sehingga munculah berbagai macam inovasi disetiap pendidikan tinggi, ada yang menjadikan teknologi sebagai brend-nya, ada yang menjadikan karakter sebagai unggulanya, dan ada yang menjadikan Religiusitas sebagai keunggulanya dengan membangun konsep Integrasi nilai-nilai Islami. Budaya yang hadir dan dihadirkan disetiap lembaga pendidikan menjadi sebuah elemen penting yang dibangun dengan nilai-nilai yang dikembangkan di dalamnya.

Universitas Muhammadiyah Metro lahir dari sebuah perserikatan Muhammadiyah yang terus berjuang dalam mencerahkan peradaban dunia dengan menegakan dan menjunjung tinggi Agama Islam sehingga terwujudnya masyarakat yang sebenar-benarnya, sebagai masyarakat bertauhid yang moderat, teladan, inklusif dan toleran, solid dan peduli sesama.

Berlandaskan pada tujuan Muhammadiyah tersebut maka sebagai amal usaha yang menjadi bagian dari Perserikatan terus melakukan gerakangerakan aktifitas keagamaan secara structural dan kultural. Universitas Muhammadiyah Metro dalam menginternalisasikan nilai-nilai Al-Islam dan kemuhammadiyan terhadap warga kampus melalui berbagai macam strategi dan kegiatan sebagaimana dikemukakan diatas. Dari langkah-langkah diaatas dapat memberikan dampak yang signifikan terhadap pemahanam dan pengamalan nilainilai Islam di dalam kehidupan individu warga kampus. Adapun nilai-nilai yang muncul pada warga kapus Universitas Muhammadiyah Metro adalah sebagai berikut:

a. Islami

Islam sebagai agama yang sempurna mengandung segala sesuatu di dalamnya mulai dari tatanan ibadah, ekonimi dan segala segi kehidupan (ibadah maupun muamalah). Maka dengan demikiaan setiap individu muslim pada hakikatnya menjiwai nilai-nilai Islam sebagai wujud ketaqwaan kepada Allah SWT sebagai Tuhan yang ditaati. Universitas Muhammadiyah Metro sebagai lembaga pendidikan milik perserikatan berbasis Islam sudah barang tentu nilai-nilai religus tumbuh dan kembang di dalamnya. Terdapat bebrapa nilai Islam yang menonjol dilingkungan 
warga kampus Universitas Muhammadiyah Metro sebagai nilai yang menghebit dalam diri masing-masing Individu seprti halnya sabar, tawakal, taubat, kerja keras dan kerjasama, tolong menolong dan lain sebagainya, nilai-nilai tersebut muncul disetiap kegiatan rutin maupun kegiatankegiatan tertentu di Universitas Muhammadiyah metro.

b. Ilmu

Ilmu menjadi sebuah ruang yang sangat vital bagi manusia dalam menentukan arah kehidupan di dunia dan akhirat hingga Rosulullah bersabda "barang siapa menginginkan dunia maka capailah dengan ilmu, dan barang siapa menginginkan akhirat, maka capailah dengan ilmu, dan barang siapa menginginkan keduanya (dunia dan akhirat) maka capailah dengan ilmu". Hal ini menunjukan bahwa ilmu memiliki kedudukan yang sangat penting didalam ajaran islam. Muhammadiyah sebagai gerakan Islam tentu tidak pernah melepaskan ilmu dan Islam sebagai pedoman utama dalam menjalali arah kehidupan, disitulan Muhammadiyah selalu berpasan terhadap warganya agar tidak melakukan taqlid buta yang tanpa mencari pengetahuan ilmunya kemudian melakukan dan mengamalkan suatu tindakan dan perbuatan sehari-hari baik dalam hubungan muamalah, aqidah dan ibadah. Dalam menggali keilmuan dunia maupun akherat Universitas Muhammadyah Metro selalu memfasilitasi seluruh warganya untuk terus belajar menggali ilmu-ilmu melalui berbagai lembaga dan unit-unit keislaman seperti halnya wakil Rektor bidang AIK, Laboratorium dakwah internal (masjid ulul albab), UPT AIK, laboratorium dakwah eksternal (masjid baiturozaq).

c. Ihsan

Nilai religious berikutnya yang hadir dilingkungan Universitas Muhammadiyah Metro adalah Ihsan. Sebagai nilai yang berasal dari kata alif, ha, sin dan nun di dalam al-Qur'an disebutkan berulangulang bahkan penyebutanya sebanyak 108 kali yang tersebar didalam 101 ayat di 36 surat. Sehingga nilai ihsan memiliki makna yang sangat dalam didalam Islam hingga Nabi pernah ditanya oleh malaikat Jibril terkait dengan Ihsan, Nabi SAW bersabda "Yaitu engkau beribadah kepada Alloh seolah-olah engkau melihat-Nya, maka apabila kamu tidak bisa (beribadah seolah-olah) melihat-Nya, maka sesungguhnya Dia melihatmu”. Ketaatan beribadah warga kampus Universitas Muhammadiyah Metro menunjukan bahwa nilai religious Ihsan sudah terbangun kedalamkopetensi pribadi dan menghebit kedalam diri.

d. Ishlah

Dilihat dari maknanya bahwa Ishlah merupakan sikap dan perbuatan yang terpuji dalam prilaku manusia. Selain itu juga bahwa kata islah memiliki sinonim seperti tajdid (pembaharuan) dan taghyir (perubahan) yang keduanya mengarah kepada pengkondisian yang lebih baik dan mengembalikan fungsinya untuk dimanfaatkan. Dalamartian islah juga adalah sebagai evaluasi diri dan saling mengkoreksi demi kebaikan dan kemaslahatan sebuah lembaga.

Ishlah yang dilakukan pemimpin, dosen dan karyawan dilakukan tidak secara umum tetapi sebaiknya dilakukan secara individu, hal ini dilakukan sebagai wujud kehati-hatian seluruh warga Universsitas Muhammadiyah Metro. Tabayyun menjadi hal yang sangat penting dilakukan disetiap pelaksanaan evaluasi dengan menggunakan evaluasu diri (ED) karena dengan tanpa adanya tabayyun akan terjadi ketidak nyamanan dan kurangnya motivasi kerja sehingga berdampak pada perkembangan lembaga. Dengan demikian BPH (Badan Pembina Harian) dan para ustadz disetiap kajian jumat selalu mengingatkan akan pentingnya evaluasi diri dan tabayyun 
sebagai wujud islah di Universitas Muhammadiyah Metro dan sebagai wujud kebersamaan dengan selalu komunikasi, konsultasi dan koordinasi akan berjalan baik untuk memajukan UM Metro ke depan.

\section{KESIMPULAN}

Universitas Muhammadiyah Metro adalah amal usaha Muhammadiyah di bidang pendidikan tinggi yang dijiwai dan dilandasi nilai-nilai Islam dan Kemuhammadiyahan pada tataran idiologis-filosofis ataupun praktis aplikatif serta menjadi salah satu kekuatan untuk kelangsungan dan kesinambungan Muhammadiyah dalam mencapai tujuannya sebagai gerakan dakwah dan tajdid yang melintasi zaman dan memiliki visi Terintegrasinya Nilai-nilai Islam dalam Kompetensi Individu dan Lembaga.

Internalisasi nilai-nilai Islam (AIK) kedalam kompetensi pribadi dosen dan karyawan dan mahasiswa UM Metro menjadi ciri khas pada penyelenggaraan pendidikan Muhammadiyah untuk membentuk manusia pembelajar yang bertaqwa, berakhlakul karimah, berkemajuan dan unggul dalam IPTEKS sebagai perwujudan tajdid dakwah amar ma'ruf nahi munkar. Sehingga strategi yang dibangun Universitas Muhammadiyah Metro dalam menginternalisasikan nilainilai adalah sebagi berikut: pertama, power strategi, dimana pimpinan rektor atau wakil rektor IV bidang AIK memiliki peran besar mengambil kebijakan dalam menentukan arah penididikan nilai. kedua, keteladanan, dalam strategi ini segenap para pimpinan di lingkungan Universitas Muhammadiyah Metro terlebih dahulu memberikan contoh sebelum mengajak para bawahanya. Ketiga, latihan pembiasaan, hal ini dilakukan pada berbagai kegiatan rutin seperti ngaji pagi, shalat dhuha, shalat berjamaah dan lain sebagainya. Keempat nasihat, nasihat dilakukan dengan tertutup sebagai wujud etika yang baik dan dilakukan oleh badan Pembina harian. Adapun kultur religious Universitas Muhammadiyah Metro pada dasarnya sudah sangat nampak secara jelas, banyak nilai nilai yang tertuang didalam kehidupan sehari hari seperti nilai Islam, Ilmu, Ihsan dan ishlah yang terbentuk dalam wujud perbuatan dan menjadi hebit dalam diri.

\section{DAFTAR PUSTAKA}

Agus Wibowo, (2012). Pendidikan Karakter, Strategi Membangun KarakterBangsa Peradaban, Yogyakarta : Pustaka Pelajar.

Ahmad Tafsir, (2004). Ilmu Pendidikan Dalam dalam Persfektif Islam, Bandung: Remaja Rosda karya Offset.

Arifin Zain. (2017). Internalisasi nilai-nilai Modernitas dalam gerakan dakwah organisasi Muhammadiyah di Aceh, Al-Idarah: Jurnal Manajemen dan Administrasi Islam. Vol. 1 No. 1 Januari - Juni.

Asmaun Sahlan. (2011). Religiusita s Perguruan Tinggi: Potret Pengembangan Tra disi Keagamaan di Pergurua $n$ Tinggi Islam. Malang: UIN-Maliki Press.

E, Mulyasa, (2012). Manajemen Pendidikan Karakter, Bandung: Rosda.

Faturrohman Muhammad. (2015). Budaya Religius Dalam Peningkatan Mutu Pendidikan: Tinjauan Teoritik dan Praktik Kontekstualisasi Pendidikan Agama di Sekolah, Yogyakarta: Kalimedia.

Heribertus Sutopo. (1988). Pengantar Penelitian Kualitatif: Dasar-Dasar Teoritis dan Praktis, Surakarta: Puslit UMS.

Herminanto dan Winarno. (2011). Ilmu Sosial dan Budaya Dasa, Jakarta: Bumi Aksara.

Khoiron Rosyadi. (2004). Pendidikan Pr ofetik, Yogyakarta: Pustaka Pelajar.

Kristiawan, M., Suhono, S., Yussof, M. H. B., \& Muslimah, M. (2021). The International School's Culture in Indonesia and Brunei Darussalam. Jurnal Iqra': Kajian Ilmu Pendidikan, 6(1), 180-191. 
Koentjaningrat. (1989). Kebudayaan, Mentalitas, dan Pembangunan. Jakarta: Gramedia.

Koentjaraningrat, 1969. Rintangan-rintangan Mental dalam Pembangunan Ekonomi di Indonesia, Jakarta : Lembaga Riset Kebudayaan Nasional.

Koentjaraningrat. (1991). "Metode Wawancara" dalam Koentjaraningrat (ed), Metode Penelitian Masyarakat. Jakarta: Gramedia.

Lexy J. Moleong. (1989). Metode Penelitian Kualitatif, Bandung: Remaja Karya.

Makmuri Muchlas, (2012). Perilaku Organisasi, Yogyakarta : Gadjah Mada University Press.

Mardalis. (2009). Metode Penelitian Suatu Pendekatan Proposal, Bumi Aksara:Jakarta.

Muhaimin, (2004). Pendidikan Agama Islam Berwawasan Rekonstruksi Sosial, Malang: UIN Malang.

Muhaimin, (2009). Rekontruksi Pendidikan Islam : Dari Paradigma Pengembangan, Manajemen Kelembagaan, Kurikulum Hingga Strategi Pembelajaran, Jakarta: PT Grafindo Persada.

Syihabuddin, (2019) Strategi Internalisasi Nilai Spiritual dalam Perspektif Guru dan Siswa Sekolah Menengah Atas di Kabupaten Bnadung Barat, Al-Tasaqofa: Jurnal Ilmiah Peradaban Islam Vol. 16 No. 2 Hal. 247-254 